\title{
Implementation of Radio Broadcasting Instructional Design as Part of C urriculum for Supporting Students' Radio Broadcasting Skill in English Department, State Polytechnic of Padang
}

\author{
SUMIRA $^{1}$, DIFIANI APRIYANTI ${ }^{2}$ \\ \#English Department, State Politechnic of Padang, West Sumatera, Indonesia \\ E-mail: sumiradoano@gmail.com \\ \#English Department, State Politechnic of Padang, West Sumatera, Indonesia \\ Email:difi_apriyanti@yahoo.com
}

\begin{abstract}
Workshop of English Radio Broadcasting is one of the subjects provided by English Department, State Polytechnics of Padang. The instructional design or syllabus of this subject is designed by English lecturers and continued by coloborating it with professional broadcasters from radio stations. In order to produce skillful students in English Radio Broadcasting, it is the duty for the lecturers to make sure wheather the objective in the instructional design has been achieved or not. Therefore, this descriptive qualitative and descriptive quantitative research is conducted to find the result. The data of the research which is applied in odd semester of academic period 2015-2016 is collected through observing the class activities and from the students Mid Test and Final Semester Test. The observation is supported by some instruments. After getting all the data, the instructional design is elaborated into checklist note. The data is then being assessed by professional radio broadcaster through intrerview. At last, the data is analyzed qualitatively. The result is most of the students have fulfilled to be a radio broadcaster, but they are not in the level of professional. It can be caused of lack practicing and it has to be delivered in English. However, these activities are a good media for students to practice their English especially for writing and speaking skills.
\end{abstract}

Keywords - Instructional design; radio broadcasting

\section{INTRODUCTION}

Every Department in an Education Institution has its curriculum. English Department, State Polytechnic of Padang which was established in 2009 has curriculum which focused on producing graduates who are skillful in English especially in broadcasting and translation area. Comparing with other English Departments at Polytechnic in Indonesia, English Department State Polytechnic of Padang (PNP) is the only one that has applied specific learning outcome. This is known during the English Department Polytechnic Meeting in
Polytechnic Lecturer Forum in Palembang, South Sumatera in 2015.

For supporting the curriculum, syllabuses (instructional designs) are conducted for every subject. Since English Department PNP focus on broadcasting, there are several subjects that support this area. In Radio Broadcasting subjects, there are syllabuses called Introduction of Broadcasting, Radio Broadcasting, and Broadcasting Workshop which are delivered to the students in semester three, four, and five.

The syllabuses of every subject have been created by lecturers who are teaching the subject in the class. For Radio Broadcaster classes, the 
syllabuses were not only written by the lecturers, but also together with professional Broadcaster from one of the radio station in Padang. These syllabuses are shown to the students in the class on their first meeting of the learning process. Therefore, the students know knowledge and skills they will gain in that semester.

The syllabuses consist of knowledge and skills that support the students to be a good radio broadcaster. They have to be professional in order to be accepted in any radio station. This expectation will not be reached if the students do not fulfilled their qualification. Therefore, a research of observing students' radio broadcasting skill is needed to measure whether the syllabus that exist now can improve students' radio broadcasting skill or not.

\section{RESUlT AND DISCUSSION}

The data was collected through check list notes that were taken during teaching and learning process of Radio Broadcasting Workshop. It is called as the primary data. The data was taken from September 2015 to January 2016. The class was held in Radio Studio of English Department State Polytechnic of Padang which consists of 43 students. The check list note was elaborated from the Radio Broadcasting Syllabus (Instructional design).

Meanwhile, to support the primary data, the researchers has also collected all the recordings of all programs that were produced by the students. It is called as secodary data. The gotten data helps in determining the students' skills and abilities which are written on the check list note .

The following diagrams show the students' achievement in acquiring skills of Radio Broadcasting:

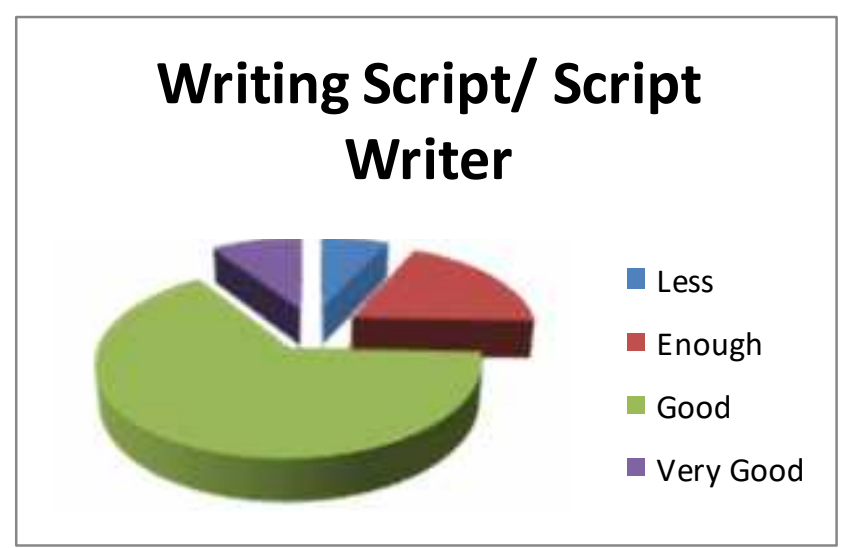

Fig 1. Students' achievement in writing script/ script writer

Based on the syllabus of Radio Broadcasting Worshop, the students must be able to write down the script for any kind of programs which are broadcasted regularly by the radio station and also script of live report. In writing the script, the students are applying the form and the rules in order to get a script which is ready to be broadcasted.

From the above Writing Script diagram, it is shown that there are three students categorized as less, eight students as enough, 28 students as good, and four students as very good.

From the observation by using checklist note and from the recording result, the students are still having problem in choosing the appropriate words and also in arranging those words into a good verbal sentences .

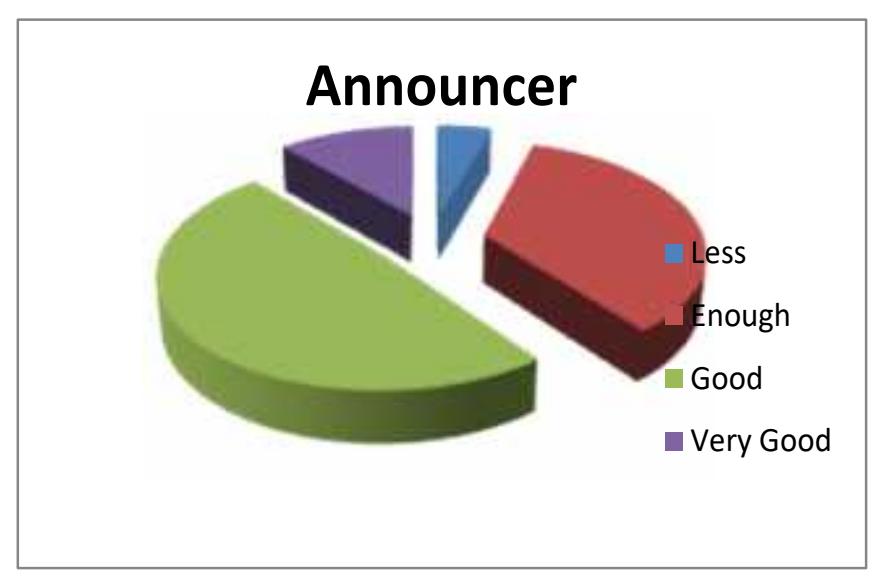

Fig 2. Students' achievement being announcer

Based on the syllabus of Radio Broadcasting Worshop, the students must be able to be a good announcer of any kinds of programs that are offered by the radio station. Therefore, the students learn about breathing and vocal technique. Since They also must know how to operate equipments that are used by the announcer. In the 
class, the students practice to be announcer in different kinds of programs. Speaking activities took most in this class

From the above Announcer diagram, it is indicated that for being an announcer, there are three students categorized as less, 15 students as enough, 21 students as good, and five students as very good.

From the observation by using checklist note and from the recording result, the students' fluency and speed still needs improvement in order to announcing, not like reading.

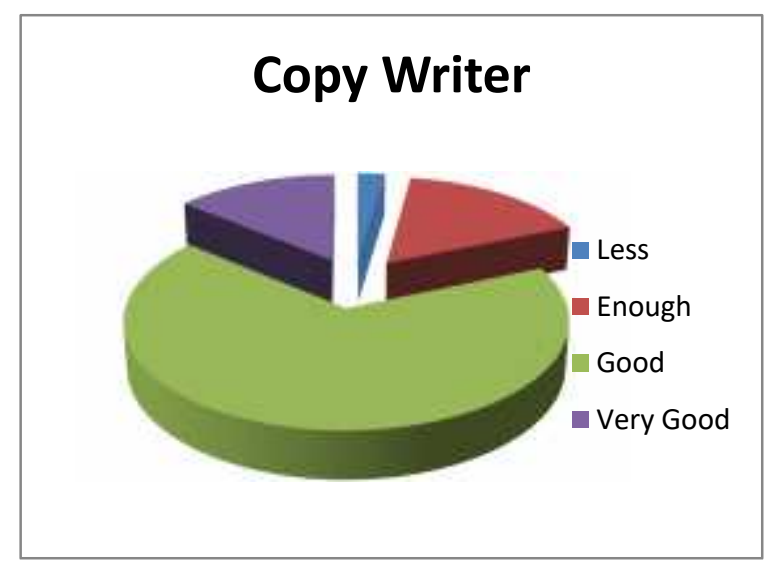

Fig 3. Students' achievement being copy writer

Based on the syllabus of Radio Broadcasting Worshop, the students must be able to be a good copy writer. They must understand completely the source of news in order to be a copy writer. They also have to know the rules of writing a news copy.

From the above Copy Writer diagram, it indicates that there is 1 student categorized as less, seven students as enough, 29 students as good, and six students as very good. Most students in the class are able to be copy writer or writing a news copy.

Although most of them are good, but from the observation by using checklist note and from the recording result, the students 'still need to practice more in selecting the most important information from the source news to be copied.

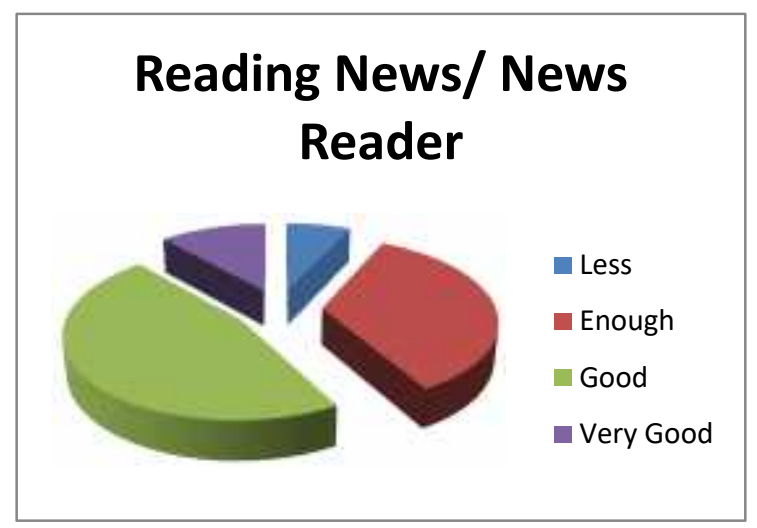

Fig 4. Students' achievement in reading news

Based on the syllabus of Radio Broadcasting Worshop, the students must be able to be a good news reader. They must be able to read the news with the right pronunciation.

From the above News Reading diagram, it indicates that for Reading News skill or being a News Reader, there are three students categorize less, 15 students are enough, 20 students are good, and 5 students are very good. Most of the students are able to be a news reader.

Although most of them are in category good and very good, but from the observation by using checklist note and from the recording result, the students 'still need to practice more in order to read the news more fluency without wrong pronunciation, and the right speed in order to be understand by the listeners.

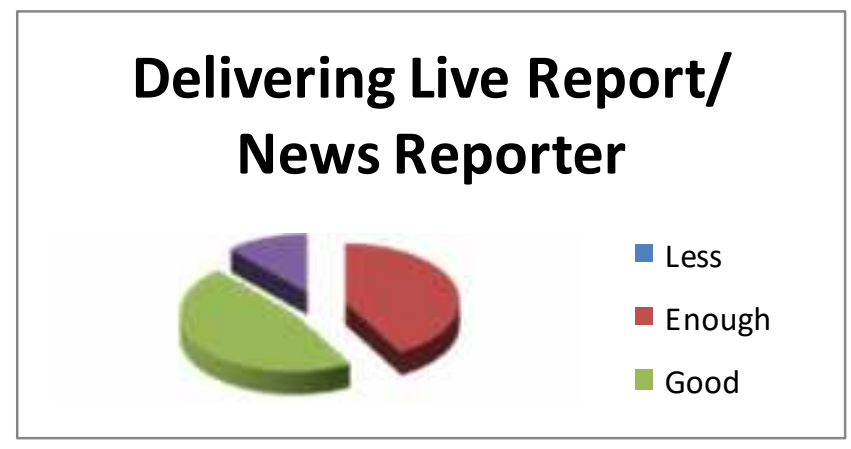

Fig 5. Students' achievement in delivering live report

From the syllabus of Radio Broadcasting workshop, the students must not only have skills in delivering news that have been set up but also live news. They must be ready to deliver or report the news directly from the spot (field).

From the above Delivering Life Report diagram, it indicates that for delivering Live Report skill or being a News Report Writer, there 
are zero students categorize less, 18 students are enough, 20 students are good, and five students are very good.

The diagram shows that the students are skillfull to be News Reporter in an life event.

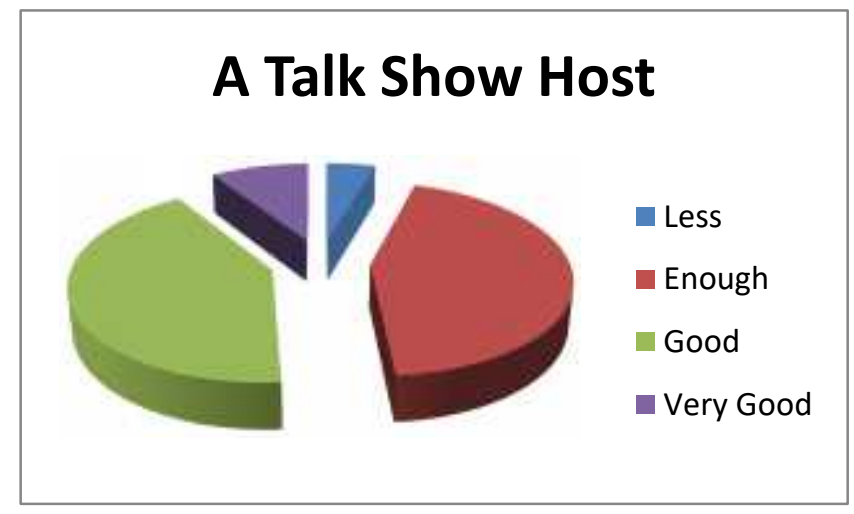

Fig 6. Students' achievement being a talk show host

Based on the syllabus of Radio Broadcasting Workshop, the students must be able to be a host of a talk show which is presented by the radio station. Before hosting, the students must learn how to create a talk show scheme.

From the above Talk Show Host diagram, it indicates that for being a host in Talk show program, there are two students categorize less, 19 students are enough, 18 students are good, and four students are very good.

Referring to the checklist note and the recording result, the students need to be more flexible and also know about the current news that happened around the world.

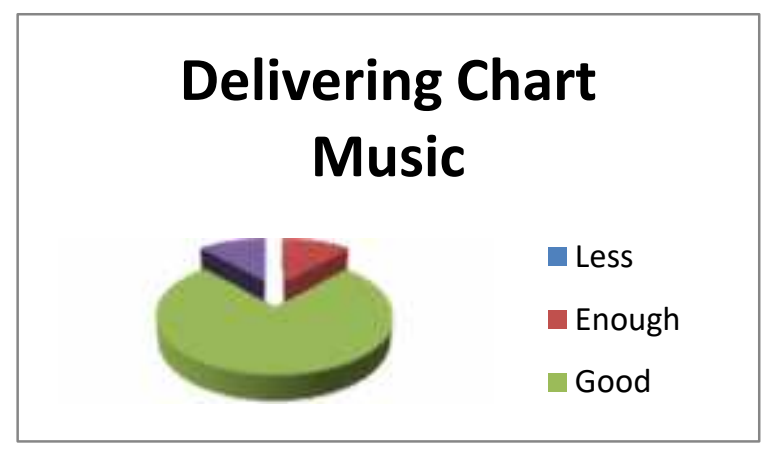

Fig 7. Students' a delivering chart music

Based on the syllabus of Radio Broadcasting Workshop, to deliver a chart music in a radio station, the students must be able to create the script or concept of the chart music, and then to arrange or listed the chart music.

From the above diagram, it indicates that for Creating and Delivering chart music skill, there are none students categorized as less, five students as enough, 33 students are good, and five students as very good.

Referring to the checklist note and the recording result, although most of the students are good, but they also must have more practicing in presenting the chart.

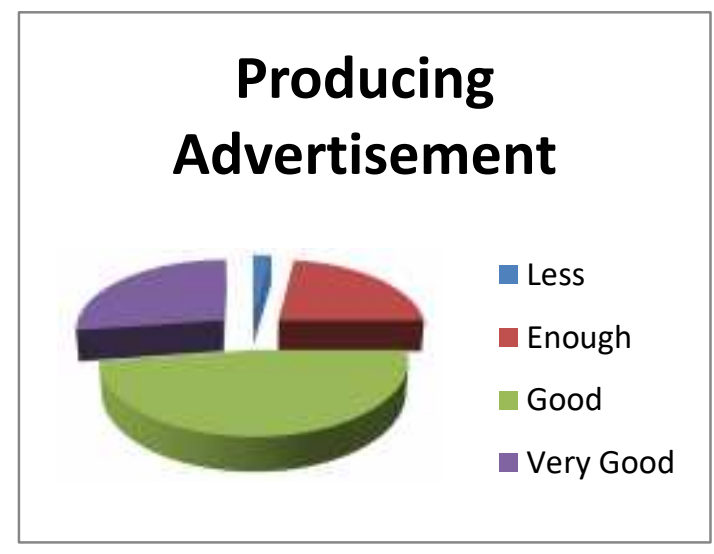

Fig 8. Students' achievement in producing advertisement

The syllabus of Radio Broadcasting Workshop provides the students to be skillfull in producing an advertisement. The students must create the scenario and scheme of the advertisement. They also must be able to do dubbing and also how to operate cool edit application.

From the above Producing Advertisement diagram, it indicates that for producing an advertisement, started from writing the script until producing advertisement product, there is one student categorized as less, 10 students as enough, 21 students as good, and 12 students as very good.

Referring to the checklist note and the recording result, although most of the students are good, but they also must have more practicing in order to produce an advertisement in a short period. 


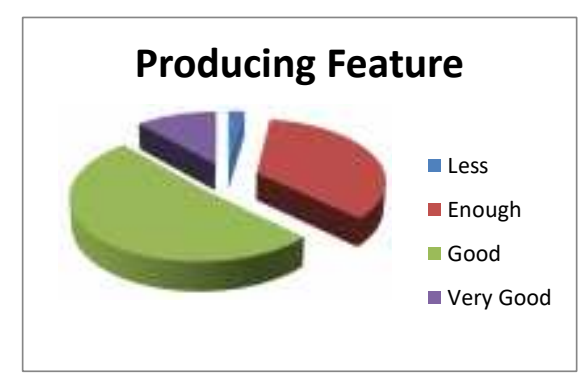

Fig 9. Students' achievement in producing feature

Based on the syllabus of Radio roadcasting Workshop, the students must be albe to create and produce a feature.

From the above Producing Feature diagram, it indicates that for producing a feature, start from writing script until having feature product, there is one student categorized as less, 15 students as enough, 22 students as good, and five students as very good.

Referring to the checklist note and the recording result, although most of the students are good, but they also must have more practicing in order to produce a feature in a short period.

For producing smash/ insert program skill that has been planned in syllabus, unfortunately, the class could not do it because of limited time due to doing the other skill; producing a feature took more than time allocation planned.

In addition, to prove all data above (primary and secondary data), the researchers also did interview with a professional radio broadcaster in Padang who also being a team teaching in radio broadcasting class due to get second opinion about the students achievement during radio broadcasting class. This data named as tertiary data. The result of the interview can be seen in appendix 3. From the open question interview, it is known that most of the students are skill full enough being radio broadcaster, even though they need more practice especially in operating the tools. Moreover the expert suggested to add more meetings for each skill provided, therefore the students will get more chance to practice and being skilful.

\section{CONCLUSION}

After conducting this research, observing the class activities due to see the students' radio broadcasting skills achievement, comparing and analyzing it with radio broadcasting instructional design, and getting interview with professional radio broadcasting, the researchers can conclude that students of English Department of State Polytechnic of Padang are skill full enough to work in broadcasting area especially in radio broadcasting. However they still need more practice and self-confident to face the real work. Hence, all of the skills that are provided in the radio broadcasting instructional design are fulfil.

\section{REFERENCES}

[1] Gay, L.R and Airasian, P. 2000. Educational Research: Competencies for Analysis. 6ed. New Jersey: Prentice-Hall Inc.

[2] Kemp, J., Morrison, G. R., Ross.,S. M . 1994. Designing Effective Instruction. United State of America: Macmillan College Publishing Company. Inc.

[3] Kurai, U. 2015. Modal-Modal Dasar Jadi Penyiar Radio. Retrieved from http://mixmradio.blogspot.com/2009/12/modal-modal-dasarjadi-penyiar-radio-html on 25 April 2015.

[4] Ornstein, A. C, \& Hunkins, F. 1988. Curriculum: Foundations, Principles, and Issues. News Jersey: Prentice Hall, Englewood Cliffs.

[5] Radiosuska. 2015. Dasar-Dasar Menjadi Penyiar Radio. Retrieved from http://tegarnawayyblogspot.com on 25 April 2015. 